\section{Intraspecific Hybridization between Non-spiny and Spiny Brinjal for Developing Non- Spiny Brinjal without Deletion of Spiny Brinjal Qualities}

\section{Pandiyan $\mathbf{M}^{1 *}$, Savitha $\mathrm{BK}^{1}$, Veeramani $\mathrm{A}^{2}$, Gopikrishnan $\mathrm{A}^{2}$, Sivakumar $C^{1}$, Krishnaveni $A^{1}$, Radhakrishnan $V^{1}$ and Vaithiya- lingan $\mathbf{M}^{1}$}

${ }^{1}$ Agricultural College and Research Institute, Tamil Nadu Agricultural University, Vazhaachanur, Thiruvannamalai, Tamil Nadu, India

${ }^{2}$ Agricultural Research Station, Tamil Nadu Agricultural University, Virinjipuram, , Vellore, Tamil Nadu, India

\begin{abstract}
An objective to develop Non-spiny brinjal without deletion of quality characters of spiny brinjal for consumers preference and also avoid hitting of spines to harvesters. Spiny brinjal (VRM-1Mullukathiri) is a pure line selection from Elavambadi village of Vellore district of Tamil Nadu. Spines are present in the leaf, stem and calyx of the fruit. VRM-1Mullukathiri is high yielding (30-35 $\left.t / h^{-1}\right)$ and most suitable for North-Eastern Zone of Tamil Nadu. From this cross of Nonspiny $x$ spiny cross combination, the VMB-012-008 was identified for big size fruit with green colour fruits. The crosses were attempted to develop non-spiny brinjal with spiny quality. The both parents of non spiny and spiny are pure for spiny and non spiny respective characters. The crossing percentage is ranged from 7.27 to 14.81 in spiny $\mathrm{x}$ non-spiny local type 3 and VRM1spiny $\mathrm{x}$ Non-spiny local type 1 respectively and Non-spiny $x$ spiny crossing percentage ranged from 9.23 to 10.74 in Non-spiny type $2 x$ VRM1 spiny type 2 and non spiny local type $3 \times$ VRM1 spiny type. The germination percentage was observed in parents ranged from 62 to 70 percent while in crosses
\end{abstract}

*Corresponding author: Pandiyan M, Agricultural College and Research Institute, Tamil Nadu Agricultural University Vazhavachanur, Thiruvannamalai, Tamil Nadu, India, Tel: + 91 9865173633; E-mail: mpandiyan8@yahoo.co.in

Citation: Pandiyan M, Savitha BK, Veeramani A, Gopikrishnan A, Sivakumar C, et al. (2020) Intraspecific Hybridization between Non-spiny and Spiny Brinjal for Developing Non-Spiny Brinjal without Deletion of Spiny Brinjal Qualities. J Plant Sci Curr Res 4: 012

Received: April 27, 2020; Accepted: June 04, 2020; Published: June 11, 2020

Copyright: (c) 2020 Pandiyan M, et al. This is an open-access article distributed under the terms of the Creative Commons Attribution License, which permits unrestricted use, distribution, and reproduction in any medium, provided the original author and source are credited. combinations ranged from 68 to 70 percent. Hybrid lethality was very low in 22.05 percent in spiny VRM1 $x$ Non-spiny type 3 and highest in spiny $\times$ Non-spiny 1 . The hybrid break down was high of 77.95 percent in VRM $1 \times$ non spiny 3 whereas low of 64.29 in spiny VRM1 $x$ Non-spiny 1 . The mean value for all the characters were recorded very high in non spiny $1 \mathrm{x}$ spiny VRM1 cross combinations.

Keywords: Brinjal; Crossability; Percentage; Fruitset; Lethality percentage; Hybrid breakdown; Mean value of various characters in $F_{1}$

\section{Introduction}

The Brinjal (Solanum melongena L.) crop belongs to the family Solanaceae, contains 75 genera and over 2000 species. The vegetable crop is considered as a native of India where the majority of domestication of large cultivars happens. The brinjal is one of the most important vegetable used by the consumers in India. Preference for brinjal consumption is varied based on location. Many brinjal types are available in Tamil Nadu. Within 50 kilometers distance consumption of brinjal preference is completely changed. Spiny brinjal having peculiar habit even in maturity stage we can use for culinary purpose. The area for spiny brinjal cultivation is very high northern Tamil Nadu and also this type fetching high price comparatively with other brinjal at the rate of at least Rs. 5 per $\mathrm{kg}$. The market value is also very high in these types. All the spiny brinjal growers happy with spiny brinjal cultivation because of continues demand. The drawback for spiny brinjal is always giving trouble to harvesters. To prevent this problem farmers are requested to scientist to eradicate this type without changing of colour, taste and qualities. Because of enquiries by the farmers through suitable research was started for developing Non spiny type without changing of characters. The research has been started in 2012 at TNAU, Agricultural Research Station, Virinjipuram, Vellore, Tamil Nadu, India.

\section{Materials and Methods}

The experimental materials namely VRM1 Spiny brinjal and non spiny local types 1,2,3 were taken for the research. Non spiny brinjal local types and Spriny brinjal variety VRM1 were raised during Rabi 2012-2013 in a crossing block. The direct and reciprocal crosses were affected following the method suggested by Boling et al. (1961) for hybridization [1]. Two types of genotypes comprised of four genotypes (only one pure variety is available in spiny brinjal namely VRM1 used as parent), three local non-spinybrinjal types were used as parents. Spines is present in all the parts of the brinjal plants viz., leaf, stem, leaves veins, peduncle, calyx, pre calyx, deep violet colour flower and ovate in spiny brinjal. Non spiny brinjal is concern the flower is light violet colour and no spines in the brinjal plant parts. The fruit shape is round. The numbers of plants survived over germinated seeds were taken to assess the lethality of $F_{1}$ hybrids.

No. of plants died

Hybrid lethality $\quad=\quad$ No. of seeds germinated 
Hybrid breakdown $=$ Number of seeds taken for germination - Hybrid lethality

The fruit set from the above mentioned crosses were sown in two rows along with one row of male and female parents with a spacing of $75 \times 30 \mathrm{~cm}$ during rabi season. The following quantitative traits were studied for all $\mathrm{F}_{1}$ hybrids. Plant height $(\mathrm{cm})$, Number of branches per plant, Length of branches $(\mathrm{cm})$, Days to 50 per cent flowering ,Number of flower per plant, Number of fruits per branch, Number of fruits per plant ,Fruit weight(g), Fruit length (cm), Number of seeds per fruits, 1000 seed weight (g), Fruit yield per plant (g), Dry matter production and Days to maturity. The observations were recorded on five randomly selected competitive plants of each experimental unit. The crossed seeds from individual plant fruits were collected separately and were sown as $\mathrm{F}_{1} \mathrm{~s}$ during kharif 2013. Observations for all the quantitative traits were recorded.

\section{Result and Discussion}

The result of this parental crosses pertaining to crossability related characters, mean performance of $\mathrm{F}_{1 \mathrm{~s}}$ morphology characters studies were carried out and revealed. The successful direct and reciprocal crosses between three non spiny brinjal 1,2,3 and one spiny brinjal VRM1 and the results were obtained from the following observations namely number of flower emasculated, number of flower crossed, fruit set and crossability percentage presented in Table 1 . In this direct cross 250, 225, 275 flowers were emasculated in Non spiny brinjal local types 1,2 and $3 \times$ Spiny brinjal VRM1 and 125, 130,121 flowers crossed from which 15.0, 12,0 and 13.0 numbers of crossed fruits obtained and 12.0, 9.23 and 10.74 fruit set percentage were recorded in above cross combinations respectively. In this reciprocal cross Spiny brinjal VRM1 x Non spiny brinjal local 1,2,3 parents 300, 235 and 210 flowers were emasculated and 135,106 and 110 flowered were crossed from which 20.0,8.0 and 8.0 Numbers of crossed fruits were obtained and 14.81, 7.54 and 7.27 fruit set percentage were recorded respectively (Table 1). Interspecific hybridization in Vigna species for many characters agree with this results by Pandiyan et al., [2-9] and in blackgram Pandiyan et al., (2008) [10]. The same results obtained by various others in different crops in soybean [11] in gingelly [12], in mungbean [13], in rice, [14], in pea plant [15], in soybean [16].

In Table 2, the parents and both direct and reciprocal cross combinations the following observations namely number of seeds germinated, hybrid lethality percentage, percentage of hybrid break down , percentage of germination and number of seedlings attained maturity were recorded .100 seeds from each parent and crosses were used. In the parents from 100 seeds used for germination only 60 to 62 percent of seeds were germinated in non-spiny brinjal types where as in spiny brinjal 70 per cent seed germination was observed. In direct cross for all non-spiny x spiny cross combinations 68.00 percent seeds were germinated while reciprocal cross spiny $\mathrm{x}$ non spiny 68 to 70 percent seeds were germinated. The hybrid lethality percentage was very low of 22.05 recorded in Spiny brinjal VRM1 x Non-spiny brinjal local 3 where as Spiny brinjal VRM1x Non-spiny brinjal local 1 recorded 35.71 percent. In direct crosses the highest lethality percentage of 33.82 was observed in the Non-spiny brinjal local $1 \times$ Spiny brinjal VRM 1 and lowest of 28.23 percentage recorded in the Nonspiny brinjal local $3 \times$ Spiny brinjal VRM 1 . In the reciprocal crosses highest percentage of hybrid lethality of 35.71 percentage in Spiny brinjal VRM1x Non spiny brinjal local 1 while lowest percentage of 22.05 recorded in Spiny brinjal VRM1 x Non-spiny brinjal local 3In direct cross namely Non-spiny brinjal local 3 x Spiny brinjal VRM 1 recorded 71.77 percent of hybrid break down and lowest of 66.18 percent in Non spiny brinjal local 1 x Spiny brinjal VRM 1 where as in reciprocal crosses highest hybrid breakdown of 77.95 percent recorded in Spiny brinjal VRM1 x Non spiny brinjal local 3 while lowest percentage of 64.29 observed in Spiny brinjal VRM1x Non spiny brinjal local 1 . The plants attained maturity after germination is varied among parents and both direct and reciprocal crosses. The plants survived after germination is highest number of 45 in Spiny brinjal VRM1 and non-spiny brinjal type 1 where very lowest of 38 numbers in Non-spiny brinjal local 3 . The plants attain maturity after germination among the cross combinations, the highest number of 25 plants survived in Spiny brinjal VRM1x Non spiny brinjal local 1 and lowest of 15.0 in Spiny brinjal VRM1 x Non spiny brinjal local 3 . In the direct crosses 23.0 number of plants attained in Non spiny brinjal local 1 x Spiny brinjal VRM 1 and lowest of 19.2 in Non spiny brinjal local 3 x Spiny brinjal VRM 1 in direct cross combinations. In reciprocal crosses a greater number of plants of 25 in Spiny brinjal VRM1x Non-spiny brinjal local 1 while lowest number of 15.0 in Spiny brinjal VRM1 x Non-spiny brinjal local 3 . The same kind of results obtained in Interspecific hybridization [2-5] in Vigna species for many characters agree with this results [6-9] and in black gram [10].

In Table 3 the Mean performance of parents and hybrids both direct and reciprocal crosses of Non-spiny and spiny VRM1 and cross Non-spiny1 x Spiny VRM1, Non-spiny2 x Spiny VRM1 , Nonspiny3 3 Spiny VRM1 and Spiny VRM 1 x Non-spiny1, Spiny VRM 1 x Non-spiny2 and Spiny VRM 1 x Non-spiny3.

For various 13 characters like PHT- Plant height (cm), NOB- number of branches, BRL- Branch length (cm), DFF- Days to fifty percent flowering, NFP- Number of fruits per plant, FPL- Fruits peduncle length, CL- Calyx length (cm), FL- Fruit length (cm), FC- Fruit circumference $(\mathrm{cm})$, FW- Average fruit weight $(\mathrm{g})$, FY- Fruit yield per plant (kg), DFM. Days to full maturity (days)

\begin{tabular}{|c|c|c|c|c|}
\hline Parents & $\begin{array}{c}\text { No. of flowers } \\
\text { emasculated }\end{array}$ & $\begin{array}{c}\text { No. of flowers } \\
\text { crossed }\end{array}$ & $\begin{array}{c}\text { No. of crossed fruits } \\
\text { obtained (fruits set) }\end{array}$ & $\begin{array}{c}\text { \% of fruit set or } \\
\text { crossability percentage }\end{array}$ \\
\hline Non-spiny brinjal local 1 x Spiny brinjal VRM 1 & 250 & 125 & 15.0 & 12.0 \\
\hline Non-spiny brinjal local 2 x Spiny brinjal VRM 1 & 225 & 130 & 12.0 & 9.23 \\
\hline Non-spiny brinjal local 3 x Spiny brinjal VRM 1 & 275 & 121 & 13.0 & 10.74 \\
\hline Spiny brinjal VRM1 x Non-spiny brinjal local 1 & 300 & 135 & 20.0 & 14.81 \\
\hline Spiny brinjal VRM1 x Non-spiny brinjal local 2 & 235 & 106 & 8.0 & 7.54 \\
\hline Spiny brinjal VRM1 x Non-spiny brinjal local 3 & 210 & 110 & 8.0 & 7.27 \\
\hline
\end{tabular}

Table 1: The crosses, fruit set and crossability percentage of different crossed parents. 
Citation: Pandiyan M, Savitha BK, Veeramani A, Gopikrishnan A, Sivakumar C, et al. (2020) Intraspecific Hybridization between Non-spiny and Spiny Brinjal for Developing Non-Spiny Brinjal without Deletion of Spiny Brinjal Qualities. J Plant Sci Curr Res 4: 012.

- Page 3 of 6 •

\begin{tabular}{|c|c|c|c|c|c|c|}
\hline Parents and Crosses & $\begin{array}{l}\text { No. of crossed } \\
\text { seeds obtained }\end{array}$ & $\begin{array}{l}\text { No. of seeds } \\
\text { germinated }\end{array}$ & Hybrid lethality (\%) & $\begin{array}{l}\% \text { of hybrid } \\
\text { break down }\end{array}$ & $\begin{array}{l}\% \text { of germi- } \\
\text { nation }\end{array}$ & $\begin{array}{c}\text { No. of seedlings attained } \\
\text { maturity }\end{array}$ \\
\hline Non-spiny brinjal local 1 & 100 & 62 & - & - & 62 & 45.0 \\
\hline Non-spiny brinjal local 2 & 100 & 62 & - & - & 62 & 42.0 \\
\hline Non-spiny brinjal local 3 & 100 & 60 & - & - & 60 & 38.0 \\
\hline Spiny brinjal VRM1 & 100 & 70 & - & - & 70 & 45.0 \\
\hline Non-spiny brinjal local 1 x Spiny brinjal VRM 1 & 100 & 68 & 33.82 & 66.18 & 68 & 23.0 \\
\hline Non-spiny brinjal local 2 x Spiny brinjal VRM 1 & 100 & 68 & 30.88 & 69.12 & 68 & 21.0 \\
\hline Non-spiny brinjal local $3 \times$ Spiny brinjal VRM 1 & 100 & 68 & 28.23 & 71.77 & 68 & 19.2 \\
\hline Spiny brinjal VRM1x Non- spiny brinjal local 1 & 100 & 70 & 35.71 & 64.29 & 70 & 25.0 \\
\hline Spiny brinjal VRM1 $\mathrm{x}$ Non- spiny brinjal local 2 & 100 & 68 & 30.88 & 69.12 & 68 & 21.0 \\
\hline Spiny brinjal VRM1 x Non- spiny brinjal local 3 & 100 & 68 & 22.05 & 77.95 & 68 & 15.0 \\
\hline
\end{tabular}

Table 2: Germination percentage of parents and F1 hybrids for direct and reciprocal crosses

\begin{tabular}{|c|c|c|c|c|c|c|c|c|c|c|c|c|}
\hline Parents /Crosses & 1.PHT & 2.NOB & 3.BRL & 4.DFF & 5.NFP & 6.FPL & 7.CL & 8.FL & 9.FC & 10.AFW & 11.FY & 12.DFM \\
\hline Non-spiny local type1. & 85.0 & 13.0 & 65.2 & 75.0 & 25.0 & 4.0 & 3.0 & 5.0 & 8.5 & 32.0 & 1.2 & 150 \\
\hline Non-spiny local type 2 . & 80.0 & 10.2 & 62.5 & 68.0 & 24.5 & 3.2 & 2.8 & 4.8 & 7.2 & 30.2 & 1.0 & 140 \\
\hline Non-spiny local type 3. & 84.5 & 12.0 & 65.0 & 66.0 & 23.5 & 3.0 & 2.5 & 4.7 & 8.3 & 32.3 & 1.3 & 145 \\
\hline Spiny VRM1 & 90.5 & 14.6 & 78.0 & 70.0 & 24.3 & 4.3 & 3.0 & 5.0 & 9.9 & 40.8 & 1.3 & 150 \\
\hline Non-spiny 1.x Spiny VRM1 & 88.5 & 15.3 & 75.3 & 78.0 & 35.0 & 4.3 & 3.0 & 5.3 & 10.7 & 46.5 & 1.8 & 150 \\
\hline Non-spiny 2.x Spiny VRM1 & 85.3 & 14.3 & 72.5 & 78.0 & 34.5 & 4.2 & 3.0 & 5.2 & 10.2 & 43.2 & 1.8 & 140 \\
\hline Non-spiny 3.x Spiny VRM1 & 86.5 & 14.0 & 75.0 & 76.0 & 33.5 & 4.0 & 2.8 & 5.1 & 10.3 & 42.3 & 1.7 & 145 \\
\hline Spiny VRM1 x Nonspiny1. & 92.5 & 15.6 & 82.0 & 72.0 & 34.3 & 4.5 & 3.0 & 5.6 & 10.9 & 46.8 & 1.9 & 150 \\
\hline Spiny VRM1 x Non-spiny2. & 90.2 & 15.7 & 79.5 & 75.0 & 33.4 & 3.8 & 2.8 & 5.3 & 10.5 & 45.2 & 1.8 & 145 \\
\hline Spiny VRM1 x Non-spiny3. & 89.5 & 16.2 & 73.5 & 72.0 & 32.4 & 3.9 & 2.9 & 5.2 & 10.3 & 43.2 & 1.8 & 145 \\
\hline
\end{tabular}

Table 3: Mean performance of parents and hybrids both direct and reciprocal crosses.

In Plant height $(\mathrm{cm})$, Non-spiny1, Non-spiny 2 and Non-spiny 3 and Spiny VRM1 registered highest value of 85.0, 80.0, 84.5 and 90.5 respectively. In the cross Non-spiny1 x Spiny VRM1 (88.5), Non-spiny 2 x Spiny VRM1 (85.3), Non-spiny3 x Spiny VRM1 (86.5) and Spiny VRM 1 x Non-spiny1 (92.5), Spiny VRM 1 x Nonspiny2 (90.2) and Spiny VRM 1 x Non-spiny3 (89.5) Number of branches per plant, in the parental species Non-spiny 1 , Non-spiny 2 and Non-spiny 3 and Spiny VRM1 registered highest value of 13.0,10.2,12.0 and 14.6 respectively. In the cross Non-spinyl $\mathrm{x}$ Spiny VRM1 (15.3), Non-spiny2 x Spiny VRM1 (14.3), Non-spiny3 x Spiny VRM1 (14.0) and Spiny VRM 1 x Non-spiny1 (15.6), Spiny VRM 1 x Non-spiny2 (15.7) and Spiny VRM 1 x Non-spiny3 (16.2). Length of branch $(\mathrm{cm})$, in the parental species Non-spiny1, Nonspiny 2 and Non-spiny 3 and Spiny VRM1 registered highest value of $65.2,62.5,65.0$ and 78.0 respectively. In the cross Non-spiny1 $x$ Spiny VRM1 (75.3), Non-spiny2 x Spiny VRM1 (72.5), Non-spiny3 $x$ Spiny VRM1 (75.0) and Spiny VRM 1 x Non-spiny1 (82.0), Spiny VRM 1 x Non-spiny2 (79.5) and Spiny VRM 1 x Non-spiny3 (73.5) Days to first flowering, in the parental species Non-spiny 1, Nonspiny 2 and Non-spiny 3 and Spiny VRM1 registered highest value of 75.0, 68.0, 66.0 and 70.0 respectively. In the cross Non-spiny1 $x$ Spiny VRM1 (78.0), Non-spiny2 x Spiny VRM1 (78.0), Non-spiny3 x Spiny VRM1 (76.0) and Spiny VRM 1 x Non-spinyl (72.0), Spiny VRM 1 x Non-spiny2 (75.0) and Spiny VRM 1 x Non-spiny3 (72.0) Number of fruits per plant, in the parental species Non-spiny1, Nonspiny 2 and Non-spiny 3 and Spiny VRM1 registered highest value of
25.0,24.5,23.5 and 24.3 respectively. In the cross Nonspiny $1 \mathrm{x}$ Spiny VRM1 (35.0), Non-spiny2 x Spiny VRM1 (34.5), Non-spiny $3 \mathrm{x}$ Spiny VRM1 (33.5) and Spiny VRM 1 x Non-spiny1 (34.3), Spiny VRM 1 x Non-spiny2 (33.4) and Spiny VRM 1 x Non-spiny 3 (32.4). The fruit peduncle length $(\mathrm{cm})$, in the parental species Non-spiny 1 , Non-spiny 2 and Non-spiny 3 and Spiny VRM1 registered highest value of 4.0,3.2,3.0 and 4.3 respectively. In the cross Non-spiny1 $x$ Spiny VRM1 (4.3), Non-spiny2 x Spiny VRM1 (4.2), Non-spiny3 $x$ Spiny VRM1 (4.0) and Spiny VRM 1 x Non-spiny1 (4.5), Spiny VRM 1 x Non-spiny2 (3.8) and Spiny VRM 1 x Non-spiny3 (3.9) Calyx length $\mathrm{cm}$, in the parental species Non-spiny 1, Non-spiny 2 and Non spiny 3 and Spiny VRM1 registered highest value of 3.0, 2.8, 2.5 and 3.0 respectively. In the cross Non-spiny1 x Spiny VRM1 (3.0), Non-spiny2 x Spiny VRM1 (3.0), Non-spiny3 x Spiny VRM1 (2.8) and Spiny VRM 1 x Non-spiny1 (3.0), Spiny VRM 1 x Non-spiny2 (2.8) and Spiny VRM 1 x Non-spiny3 (2.9) Fruit length $\mathrm{cm}$, in the parental species Non-spiny 1 , Non-spiny 2 and Non-spiny 3 and Spiny VRM1 registered highest value of 5.0, 4.8, $4 . .7$ and 5.0 respectively. In the crosses, Non-spiny1 x Spiny VRM1 (5.3), Non-spiny2 x Spiny VRM1 (5.2), Non-spiny3 x Spiny VRM1 (5.1) and Spiny VRM 1 x Non-spiny1 (5.6), Spiny VRM 1 x Non-spiny2 (5.3) and Spiny VRM $1 \mathrm{x}$ Non-spiny3 (5.2). Fruits circumbrance $(\mathrm{cm})$ for this trait in the parental species Non-spiny 1 , Non-spiny 2 and Non-spiny 3 and Spiny VRM1 registered highest value of 8.5, 7.2, 8.3 and 9.9 respectively. In the cross Non-spiny1 x Spiny VRM1 (10.7), Non-spiny2 x Spiny VRM1 (10.2), Non-spiny3 x Spiny VRM1 (10.3) and Spiny VRM 
Citation: Pandiyan M, Savitha BK, Veeramani A, Gopikrishnan A, Sivakumar C, et al. (2020) Intraspecific Hybridization between Non-spiny and Spiny Brinjal for Developing Non-Spiny Brinjal without Deletion of Spiny Brinjal Qualities. J Plant Sci Curr Res 4: 012.

- Page 4 of 6 •

1 x Nonspiny1 (10.9), Spiny VRM 1 x Non-spiny2 (10.5) and Spiny VRM $1 \times$ Non-spiny3 (10.3) Average fruit weight (g) in the parental species Non-spiny 1, Non-spiny 2 and Non-spiny 3 and Spiny VRM1 registered highest value of 32.0, 30.2, 32.3 and 40.8 respectively. In the cross Non-spiny1 x Spiny VRM1 (46.5), Non-spiny2 x Spiny VRM1 (43.2), Non-spiny3 x Spiny VRM1 (42.3) and Spiny VRM 1 x Non-spiny1 (46.8), Spiny VRM 1 x Nonspiny2 (45.2) and Spiny VRM 1 x Non-spiny3 (43.2) Fruit yield (g) in the parental species Non-spiny 1 , Non-spiny 2 and Non-spiny 3 and Spiny VRM1 registered highest value of 1.2, 1.0, 1.3 and 1.3 respectively. In the cross Non-spiny1 x Spiny VRM1 (1.8), Non-spiny2 x Spiny VRM1 (1.8), Non-spiny3 x Spiny VRM1 (1.7) and Spiny VRM 1 x Non-spiny 1 (1.9), Spiny VRM 1 x Non-spiny2 (1.8) and Spiny VRM 1 x Nonspiny3 (1.8) Days to full maturity, in the parental species Non-spiny 1 , Non-spiny 2 and Non-spiny 3 and Spiny VRM1 registered highest value of $150,140,145$ and 150 respectively. In the cross Non-spiny1 $x$ Spiny VRM1 (150), Non-spiny2 x Spiny VRM1 (85.3), Non-spiny3 $x$ Spiny VRM1 (140) and Spiny VRM 1 x Non-spiny1 (145), Spiny VRM 1 x Non-spiny2 (90.2) and Spiny VRM 1 x Non-spiny3 (150). This result agrees with Interspecific hybridization in Vigna species for many characters [2-5] in Vigna species for many characters agree with this result [6-9] and in blackgram [10]. Mean performance in interspecific progenies of brinjal [17]. The same result was obtained in different vegetable crops [18-20] and observed in brinjal crop [2126]. Amirthanayagam (2001) [27] reported in okra (Abelmoschus esculentus (L.) Moench.). The same result of qualitative transformation was observed in Solanum melongena L. [28-30] and [31] Rao and Kumar (1980).

\section{Botanical and morpho- agronomic description of New crossed} line Non-spiny brinjal VMB -012-008

- Non-spiny brinjal VMB -012-008 is a cross derivative of Nonspiny Brinjal local 1 x VRM-1 Spiny brinjal of Thiruvannamalai and Vellore Districts, Tamil Nadu, India.

- Spines are absent in the leaf, stem and calyx of the fruit but the quality of the fruit remains same as VRM-1 Spiny Brinjal.

- It is cluster bearing in nature. Non spiny nature. Fruits are oval in shape, glossy green colour in colour

- It is of medium duration (140-150days)

- Average single fruit weigh is $365 \mathrm{~g}$

- Length of the fruit $15 \mathrm{~cm}$ and girth is $28.6 \mathrm{~cm}$

- Number of fruits per plant is 10-12

- Yield per plant $(\mathrm{Kg}) 3.5$ to 4.5

- Yield per ha $(\mathrm{Kg}) 45$ to 50 tons

- Flesh content is more and seed content is less. Suitable for all types of culinary preparations, especially highly suitable for preparations of side dish to biryani, Main dish like sambar, vathalkushambu, poriyal and highly suitable for baggy for evening snacks

- Performs well under wide range of soil with good drainage facility and suitable to cultivate in all three seasons (Kharif, Rabi and summer)

- Tolerant to drought conditions and high temperature prevailing during summer months.

- It is found to be highly resistant to little leaf incidence and moderately resistant to Tobacco Mosaic Virus (TMV) and fruit and shoot borer

- Increased yield over check (\%) 15.32

\section{Conclusion}

The crossing between the Non-spiny brinjal local $1 \times$ Spiny brinjal VRM1 had well expressed almost all quantitative and qualitative characters in the new brinajal culture. The culture name has been given as VMB-012-008. It is green colour medium to big size fruits preferred by the consumers. Out of the best performing crosses, this cross had consecutively performed well over generations for growth, yield and non-spiny nature. This new brinjal culture can be used as donor in the appropriate breeding programme for developing non spiny brinjal types with retaining original native spiny brinjal taste in terms of quality.

\section{References}

1. Bolling M, Sander D, Matlock RS (1961) Mungbean hybridization Technique. Agron J 53:54-55.

2. Pandiyan M, Senthil N, Ramamoorthi N, Muthiah AR, Tomooka N, et al. (2010) Interspecific hybridization of Vigna radiata x 13 wild Vigna species for developing MYMV donar. Electronic Journal of Plant Breeding 1: 600-610.

3. Pandiyan M, Senthil N, Suersh R, Chakravarthy N, Packiaraj D, Jagadeesh $\mathrm{S}$ (2012) Interspecific hybridization of Vigna radiate $x$ Vigna trilobata. Wudpecker. Journal of Agricultural Research 1: 233 -234.

4. Pandiyan M (2012) VBG-09-012 (INGR11045) and Urd Bean (Vigna mungo) Germplasm with Multi-Pod Formation at Base of Peduncle, Leaf Axils and Base of Clusters. Indian Journal of Plant Genetic Resources 26: 90-90.

5. Pandiyan M, Senthil N, Sivakumar P, Muthiah AR, Ramamoorthi N (2010) Genetic diversity analysis among greengram genotypes using RAPD markers. Electronic Journal of Plant Breeding 1: 466-473.

6. Pandiyan M, Geetha S, Packiaraj D, Thiyagarajan K, Senthil N (2012) VBG-04-014 (IC0589272; INGR11046) and Urd Bean (Vigna mungo) Germplasm with Unique Plant Type. Indian Journal of Plant Genetic Resource 26: 91-91.

7. Pandiyan M, Senthil N, Anitha M, Raveendran M, Sudha M, et al. (2012) Diversity analysis of Vigna sp. through morphological markers. Wudpecker Journal of Agricultural Research 1: 335-340.

8. Pandiyan M, Geetha S, Gnanamalar RP, Packiaraj D, Mahalingam A, et al (2018) A new high yielding MYMV disease resistant blackgram variety VBN 8. Electronic Journal of Plant Breeding 9: 1272-1279.

9. Pandiyan M, Senthil N, Suersh R, Chakravarthy N, Ackiaraj D, et al. (2012) Interspecific hybridization of Vigna radiata x Vigna trilobata. Wudpecker Journal of Agricultural Research 1: 233-234.

10. Pandiyan M, Ramamoorthi N, Ganesh SK, Jebaraj S, Nagarajan P, et al. (2008) Broadening the genetic base and introgression of MYMV resistance and yield improvement through unexplored genes from wild relatives in mungbean. Plant Mutation Reports 2: 33-43.

11. Mahbub MM, Rahman MM, Hossain MS, Mahmud F, and Kabir MMM (2015) Genetic variability, correlation and path analysis for yield and yield components in soybean. American-Eurasian Journal of Agricultural \& Environmental Sciences 15: 231-236.

12. Shirazy BJ, Islam MM, Haque MA, Mahbub MM and Somee TA (2015) Influence of Combined Effect of Nitrogen and Micronutrients on Yield and Yield Contributing Characters of Sesame (Sesamum indicum L.). Botany Research International 8: 73-76.

13. Hossain MM, Mahbub MM, and Shirazy BJ (2016) Growth and Yield Performance of Mungbean Varieties in Summer Cultivation. Scientia Agriculturae 16: 79-82. 
14. Shirazy BJ, Rashid MH, Mahbub MM, Somee TA, Goswami PC (2016) Farmers' Participatory Demonstration of Salt Tolerant T. Aman Rice Varieties in Saline Soils. Academic Journal of Plant Sciences 9: 01-04.

15. Khan MRA, Mahbub MM, Reza MA, Shirazy BJ, Mahmud F (2016) Selection of Field Pea (Pisum sativum L.) Genotypes through Multivariate Analysis. Scientia Agriculturae 16: 98-103.

16. Mili KN, Shirazy BJ, and Mahbub MM (2017) Screening of Soybean (Glycine $\max$ L.) Genotypes through Multivariate Analysis. Azarian Journal of Agriculture 4: 1-6.

17. Prabhu MS, Natarajan L, Pugalendhi M, Prabhu S, Natarajan L, et al (2011) Mean performance of eggplant (Solanum melongena L.) inter-specific progenies. Indian J Agric Res 45: 249 - 252.

18. Nolla JAB (1932) Inheritance of color in eggplants (S. melongena L.). J Dept of Agri Puerto Rio 16: 19-30.

19. Sinha BK, Prakash, R. Haque, Md. (1966) F1Linkage study in brinjal (Solanum melongena L.). Indian J Genet, 26: 223-226.

20. Swamy Rao T (1970) A preliminary note on the inheritance of qualitative characters in brinjal (Solanum melongena L.). Madras agric J 57: 508-509.

21. Wanjari KB, Khapre PR (1977) Inheritance of pigmentation in S. melongena $x$ S. indicum. Genet Agraria 31: 327-332.

22. Rao N, Ponnaiya BWX, Menon PM (1969) Studies on the interspecific hybrids of non-tuberiferous species of $S$. melongena L. South Indian Hort 17: $71-78$
23. Khapre PR, Wanjari KB Deokar KB (1986) Inheritance of some fruit color in S. melongena x S.indicum. J Mahar Agric Univ 13: 97-98.

24. Rangaswamy P, Kadam Bavansundaram M (1973) A study on the inheritance of certain qualitative characters in the cross between $S$. indicum $x S$ melongena. South Indian Hort 21: 1-6.

25. Nimbalkar VS, More DC (1980) Genetic studies in a brinjal cross Muktakeshi x White green. J Mahar Agric Univ 5: 208-210.

26. Patil SK, More DC (1983) Inheritance studies of some characters in brinjal. J. Maharashtra Agric Uni 8: 47-49.

27. Amirthanayagam ERM (2001) Genetic variability studies in F4 and F5 generations of okra (Abelmoschus esculentus (L.) Moench.). M.Sc., (Hort.) Thesis.2001, Tamil Nadu Agricultural University, Coimbatore.

28. Behera TK, Singh N (2002) Interspecific hybridization in eggplant for resistance to shoot and fruit borer. Capsicum Eggplant News Letter 21: 102-105.

29. Krishnaiah K (1980) Assessment of crop losses due to pests and diseases (Ed. H.C. Govindu). U.A.S. Tech. Series 33: 259-267.

30. Preneetha S (2002) Breeding for shoot and fruit borer (Leucinodes orbonalis G.) resistance in brinjal (Solanum melongena L.). Ph.D., (Hort.) Thesis 2002, Tamil Nadu Agricultural University, Coimbatore.

31. Rao GR, Kumar A (1980) Some observations on interspecific hybrids of Solanum melongena L. Proc. Indian Acad Sci 87: 117-121. 


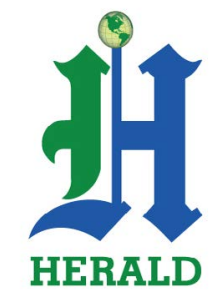

Submit Your Manuscript: https://www.heraldopenaccess.us/submit-manuscript

Herald Scholarly Open Access, 2561 Cornelia Rd, \#205, Herndon, VA 20171, USA.

Tel: +1-646-661-6626; E-mail: info@heraldsopenaccess.us

http://www.heraldopenaccess.us/ 